\title{
Patent Protection Management for Research Results of Research Entities in Poland
}

\author{
Joanna WIŚNIEWSKA and Krzysztof JANASZ
}

University of Szczecin, ul. Mickiewicza , Szczecin, Poland

\begin{abstract}
Correspondence should be addressed to: Krzysztof JANASZ; krzysztof.janasz@usz.edu.pl
Received date: 28 February 2018; Accepted date: 31 May 2018; Published date: 25 July 2018.

Academic Editor: Beata Ślusarczyk

Copyright @ 2018. Joanna WIŚNIEWSKA and Krzysztof JANASZ. Distributed under Creative Commons CC-BY 4.0
\end{abstract}

\begin{abstract}
The challenges of the modern world and the development of individual economies require the implementation of various types of innovations based on knowledge and technology resources. For this reason, the role of research and development activity - carried out by various entities - has grown significantly in Poland as well. Due to the nature and scope of its research activities, the academic sector plays a specific role in this group. The aim of the article is to identify the scope and primary conditions for the patent protection management of the research results of scientific units in Poland, with particular emphasis on the situation of higher education institutions. The research undertaken, indicating selected phenomena accompanying the patent protection management of the research results of scientific and research entities, highlights some of the existing problems and dilemmas which must be solved i.e. still insufficient knowledge and experience of the scientific community in the relevant area, variable legal and regulatory conditions, costs and finance-related problems.The study was based on an analysis of domestic and foreign literature, analyses based on data provided by the Central Statistical Office in Poland, Eurostat, Polish Patent Office, European Patent Office and the use of deductive and inductive reasoning.
\end{abstract}

Keywords: R\&D, research entities, patent protection management

\section{Introduction}

Concern for the economic development of the country, strengthened by the fear of falling into the so-called 'middle income trap', justifies the need to increase innovation by moving away from the exogenous, i.e. imitative, model and towards an endogenous model based on independent creation processes and using knowledge to spark innovation and technological progress. Such an approach requires strengthening activities aimed at stimulating research and development, the results of which would be widely used in economic practice and would contribute to the dynamic development thereof. The idea is to create innovations based to a greater extent on Polish ideas and discoveries. In the long term, only such discoveries can

Cite this Article as: Joanna WIŚNIEWSKA and Krzysztof JANASZ (2018)," Patent Protection Management for Research Results of Research Entities in Poland", Journal of Eastern Europe Research in Business and F.conomics. Vol. 2018 (2018). Article ID 263.329. DOI: 10.5171/2018.263.329 
provide a competitive edge to both individual entities and to the economy as a whole.
Research and development work in Poland is undertaken by a diverse range of entities, whose number - as indicated by statistics is consistently increasing (Table 1).

Table 1: Number of entities in Poland incurring internal R\&D Expenditure in 2012-2015

\begin{tabular}{|l|r|r|r|r|}
\hline Sector & $\mathbf{2 0 1 2}$ & $\mathbf{2 0 1 3}$ & $\mathbf{2 0 1 4}$ & $\mathbf{2 0 1 5}$ \\
\hline Commercial & 2127 & 2467 & 2814 & 3735 \\
\hline Governmental & 326 & 343 & 360 & 374 \\
\hline Higher education & 217 & 222 & 217 & 219 \\
\hline $\begin{array}{l}\text { Private non-commercial } \\
\text { institutions }\end{array}$ & 63 & 90 & 83 & 99 \\
\hline Total & 2733 & 3122 & 3474 & 4427 \\
\hline
\end{tabular}

Source: Based on data from Central Statistical Office in Poland

Due to the nature of the research they conduct, higher education institutions hold a special place among this group, as conducting scientific research is one of their basic functions. Furthermore, unlike other entities, higher education institutions carry out a full range of research (basic research, applied research, and development).

For many years, Polish innovation policy has been focused on increasing overall involvement in R\&D activities not only on the part of research entities, but especially on the part of commercial entities (Máté, Oláh, Laknern, Popp, 2016, 163). The intensification and development of cooperation between both sectors is of particular importance. The point is that entities specializing in the acquisition of new knowledge (scientific entities) should discover and create new solutions in areas of practical interest - enterprises which, by their very nature, usually have greater expertise in commercialization. As such, new knowledge can be used in the most effective way possible, which allows for achieving the goal of intensive development of both individual entities and the country as a whole. The result of using such a variety of tools and support programs, the level of $R \& D$ expenditure in Poland is gradually increasing, though is still not satisfactory (Table 2). It should be emphasized that the government also takes part in R\&D activities, primarily in the higher education sector, stateadministered research institutions, and other non-commercial organizations (Sawulski, 2018, 40).

Table 2: Internal R\&D expenditures in million EUR (GERD)

\begin{tabular}{|l|r|r|r|r|r|}
\hline Sector & $\mathbf{2 0 1 2}$ & $\mathbf{2 0 1 3}$ & $\mathbf{2 0 1 4}$ & $\mathbf{2 0 1 5}$ & $\mathbf{2 0 1 6}^{*}$ \\
\hline Commercial & 1276.34 & 1498.80 & 1800.09 & 2010.33 & 2700.43 \\
\hline Governmental & 958.95 & 921.93 & 925.53 & 1052.99 & 103.37 \\
\hline Higher education & 1181.02 & 1005.43 & 1126.78 & 1246.43 & 1290.43 \\
\hline $\begin{array}{l}\text { Private non-commercial } \\
\text { institutions }\end{array}$ & 13.55 & 10.10 & 11.61 & 6.79 & 18.13 \\
\hline Total & 3429.85 & 3436.28 & 3864.01 & 4316.51 & 4112.35 \\
\hline
\end{tabular}

* Provisional data, unverified

Source: Based on data form Eurostat

In practice, from the perspective of impact on increasing innovation and economic development levels, the research results of the greatest value are those which are 
suitable for practical use, those with commercial potential. According to the report on the $R \& D$ resources of Polish scientific entities prepared for the National Centre for Research and Development (NCBiR), in the period of six years (2015 2020), approximately 1000 - 1200 projects may be subject to commercialization, of which the total estimated value is about EUR 2.5 billion (NCBiR Report, 2015, 5-6).

From the point of view of development, technical inventions which have enormous potential for creating innovation in terms of new processes, technologies and products are of particular strategic importance. For this reason, such inventions and innovations - the results of scientific research - require special attention and an appropriate approach in the intellectual property protection and commercialization processes.

\section{The Concept of Scientific Research and the Legal Means of Protection Thereof}

A review of both the literature on the subject and Polish legislation allows us to conclude that there is no uniform definition of the term "scientific research results." An analysis of the provisions of the Act on the principles of financing science (Act of 30 April 2010) indicates that scientific research leads to "acquiring new knowledge."

In turn, art. 86a of the Law on Higher Education (2016) indicates that the results of scientific research may be both objects of industrial property rights (e.g. inventions, utility models, industrial designs, integrated circuit designs, etc.), and take a completely different dimension, e.g. as the result of artistic creation, therefore having the form of an artistic work.

The nature of the results of scientific research can be scientific (cognitive), i.e. leading to better recognition of reality and thus broadening the general state of knowledge, but also having a certain pragmatic value, i.e. the possibility of practical applications. While in the first case it would be important to disseminate the research results as widely as possible, i.e. without restrictions, considering the use of results in business practice, i.e. through the prism of the potential commercialization processes, the issue of protection thereof may play a significant role.

The indicated diversity of the forms of scientific research results in the particular complexity of the protection process. There is no one means of protection applicable to every possible form of scientific research results. Even considering only the two most common forms of research results (i.e. works and objects of industrial property), the scope of existing legal tools and practical methods of protection is extensive. In essence, there are two means of protection, overt - based on obtained intellectual property rights, and covert based on maintaining secrecy.

The objects of industrial property rights and artistic works may be protected based on the monopoly resulting from the provisions of both copyright law and industrial property law. While there are no formal conditions to be fulfilled for copyright protection (it is enough for the research results to be artistic works), applying for industrial property protection requires the completion of certain formalities at the patent office.

Formal legal protection of research results constituting industrial property is connected with the need to conduct specific administrative procedures (notification, verification, exclusive rights, etc.) and pay certain fees. The scope of required actions and procedures depends on the object of protection. Of such, the widest concerns inventions requiring patent protection.

From the point of view of scientific entities, among the various types of research results, inventions which may be patent protected are the most significant.

It should be noted that patent protection is fundamentally dependent on two basic issues, i.e. whether the invention may be covered by patent protection (whether it 
meets the criteria set by law) and whether it is necessary to seek such protection. However, meeting the indicated requirements does not necessarily mean that applying for patent protection is necessary. Similarly, failing to fulfil such requirements does not necessarily mean that such inventions should not be submitted to the patent office.

If the protection of research results in a transparent manner is impossible or unjustified, it may be important to keep such results secret, which in practice means disallowing publication as well as physical and formal restriction of third party access. In this case, the obtained research results are treated as confidential, and access to such may be granted using a modular approach or the principle of gradual dissemination of information. The modular approach means full access to all information (contained in all modules) only for a small group of people. In this situation, other participants have access only to partial results. In turn, the principle of gradual dissemination means the division of information related to the obtained results into several categories, e.g. public information, information provided to contractors after signing a confidentiality agreement, and key information made available only as a result of a commercialization contract, e.g. a license agreement.

\section{Patent protection activity in Poland}

According to an analysis of statistical data, the interest in the legal protection of intellectual property (including inventions) in Poland is growing systematically. This indicates a growing number of patent applications filed and patents obtained (Table 3).

Table 3: Number of and change in patent applications and patents granted to domestic entities from 2010-2016

\begin{tabular}{|l|r|r|r|r|r|r|r|}
\hline Description & $\mathbf{2 0 1 0}$ & $\mathbf{2 0 1 1}$ & $\mathbf{2 0 1 2}$ & $\mathbf{2 0 1 3}$ & $\mathbf{2 0 1 4}$ & $\mathbf{2 0 1 5}$ & $\mathbf{2 0 1 6}$ \\
\hline $\begin{array}{l}\text { Number of patent } \\
\text { applications submitted to the } \\
\text { Polish Patent Office }\end{array}$ & 3203 & 3878 & 4410 & 4237 & 3941 & 4676 & 4261 \\
\hline Year on year change as a \% & 100 & 121 & 114 & 96 & 93 & 119 & 91 \\
\hline $\begin{array}{l}\text { Patents granted to domestic } \\
\text { entities by the Polish Patent } \\
\text { Office }\end{array}$ & 1385 & 1989 & 1848 & 2339 & 2490 & 2404 & 3370 \\
\hline Year on year change as a \% & 100 & 144 & 93 & 127 & 106 & 97 & 140 \\
\hline $\begin{array}{l}\text { Number of European patents } \\
\text { validated in Poland }\end{array}$ & 4516 & 5790 & 6710 & 7236 & 7380 & 7883 & 9871 \\
\hline Year on year change as a \% & 100 & 128 & 116 & 108 & 102 & 107 & 125 \\
\hline $\begin{array}{l}\text { Number of patent } \\
\text { applications filed with EP0 by } \\
\text { Polish entities }\end{array}$ & 205 & 246 & 383 & 372 & 482 & 566 & 619 \\
\hline Year on year change as a \% & 100 & 120 & 156 & 97 & 130 & 117 & 109 \\
\hline $\begin{array}{l}\text { Patents granted to Polish } \\
\text { entities by the EPO }\end{array}$ & 44 & 45 & 80 & 95 & 108 & 151 & 180 \\
\hline Year on year change as a \% & 100 & 102 & 178 & 119 & 114 & 140 & 119 \\
\hline
\end{tabular}

Source: Own study based on Polish Patent Office (PPO) and European Patent Office (EPO) data 
In the analysed period, the total number of patent applications submitted to the Polish Patent Office increased by over 33\%, and the number of patents granted to domestic entities increased by over $140 \%$. A more than threefold increase in the number of applications filed by domestic entities to the EPO should be assessed positively. Unfortunately, despite this, applications for patent protection outside Poland by Polish entities are still far fewer than such applications by entities from more developed countries. In 2016, patent applications from Poland accounted for only approximately $0.3 \%$ and $0.2 \%$ of the total number of applications and the total number of patents granted, respectively, by the EPO. It should be noted that Poland is indicated increasingly often in patent protection implementation procedures conducted through the EPO. The number of European patents validated in Poland has increased by over $118 \%$ since 2010 .

The activity of universities in terms of the number of patent applications filed with the Polish Patent Office (Table 4) is noteworthy.

Table 4: Ranking of the top 10 entities which filed for intellectual property protection with the Polish Patent Office in 2015 and 2016. (more than 20 patents and protection for utility models)

\begin{tabular}{|c|l|c|}
\hline Position & Name & Number of applications \\
\hline \multicolumn{2}{|c|}{2015} & 119 \\
\hline 1 & Wrocław University of Technology & 115 \\
\hline 2 & West Pomeranian University of Technology & 109 \\
\hline 3 & AGH University of Science and Technology & 97 \\
\hline 4 & Lublin University of Technology & 86 \\
\hline 5 & Silesian University of Technology & 83 \\
\hline 6 & Krakow University of Technology & 72 \\
\hline 7 & Poznan University of Technology & 70 \\
\hline 8 & University of Wroclaw & 69 \\
\hline 9 & Lodz University of Technology & 65 \\
\hline 10 & Warsaw University of Technology & 194 \\
\hline & \multicolumn{1}{|c|}{2016} & 134 \\
\hline 1 & Wrocław University of Technology & 106 \\
\hline 2 & AGH University of Science and Technology & 97 \\
\hline 3 & Lodz University of Technology & 93 \\
\hline 4 & Lublin University of Technology & 80 \\
\hline 5 & Warsaw University of Technology & 70 \\
\hline 6 & Silesian University of Technology & 68 \\
\hline 7 & Poznan University of Technology & 61 \\
\hline 8 & Industrial Institute of Automation and Measurements & 60 \\
\hline 9 & West Pomeranian University of Technology & \\
\hline 10 & Institute for Sustainable Technologies - National & \\
\hline & Research Institute & \\
\hline
\end{tabular}

Source: Our own analysis of information from the Polish Patent Office

It is worth noting that the share of applications submitted to the Polish Patent Office represented by scientific research entities (including: universities, research institutes, units of the Polish Academy of Sciences) has been similar for years, accounting for a total of around $45 \%$ of all applications. Of such, higher education 
institutions account for over 50 percent. Similarly, when it comes to applying for the
European patents, universities are the leaders in Poland (Table 5).

Table 5: Ranking of organizations reporting the highest number of patent applications to the EPO in 2015 and 2016

\begin{tabular}{|c|c|c|c|c|}
\hline Position & Entities from Poland & $\begin{array}{c}\text { Number of } \\
\text { applications }\end{array}$ & $\begin{array}{l}\text { International } \\
\text { entities }\end{array}$ & $\begin{array}{l}\text { Number of } \\
\text { applications }\end{array}$ \\
\hline \multicolumn{5}{|c|}{2015} \\
\hline 1 & $\begin{array}{l}\text { Gdansk University of } \\
\text { Technology }\end{array}$ & 23 & Philips - EU & 2402 \\
\hline 2 & $\begin{array}{l}\text { AGH University of Science } \\
\text { and Technology }\end{array}$ & 22 & $\begin{array}{l}\text { Samsung - South } \\
\text { Korea }\end{array}$ & 2366 \\
\hline 3 & $\begin{array}{l}\text { International Tobacco } \\
\text { Machinery }\end{array}$ & 14 & LG - South Korea & 2091 \\
\hline 4 & $\begin{array}{l}\text { HS Wrocław SP. z o.o. } \\
\text { [Ltd.] }\end{array}$ & 11 & Huawei - China & 1953 \\
\hline 5 & $\begin{array}{l}\text { Lodz University of } \\
\text { Technology }\end{array}$ & 11 & Siemens - EU & 1894 \\
\hline 6 & $\begin{array}{l}\text { Poznan University of } \\
\text { Technology }\end{array}$ & 10 & $\begin{array}{l}\text { United Technologies - } \\
\text { USA }\end{array}$ & 1869 \\
\hline 7 & Selvita S.A. [Inc.] & 10 & Qualcomm - USA & 1705 \\
\hline 8 & University of Szczecin & 10 & Robert Bosch - EU & 1439 \\
\hline 9 & $\begin{array}{l}\text { Pharmaceuticals } \\
\text { Polpharma S.A. [Inc.] }\end{array}$ & 9 & BASF - EU & 1384 \\
\hline 10 & $\begin{array}{l}\text { Bomar S.A. [Inc], in } \\
\text { administration }\end{array}$ & 8 & General Electric - USA & 1316 \\
\hline \multicolumn{5}{|c|}{2016} \\
\hline 1 & Jagiellonian University & 12 & Philips - EU & 2568 \\
\hline 2 & $\begin{array}{l}\text { Pharmaceuticals } \\
\text { Polpharma S.A. [Inc.] }\end{array}$ & 10 & Huawei - China & 2390 \\
\hline 3 & Fakro Sp. z o.o. [Ltd.] & 6 & $\begin{array}{l}\text { Samsung - South } \\
\text { Korea }\end{array}$ & 2316 \\
\hline 4 & $\begin{array}{l}\text { Wroclaw Research Centre } \\
\text { EIT + Sp z o.o. [Ltd.] }\end{array}$ & 6 & LG - South Korea & 2313 \\
\hline 5 & $\begin{array}{l}\text { Polish Academy of } \\
\text { Sciences Space Research } \\
\text { Centre }\end{array}$ & 4 & $\begin{array}{l}\text { United Technologies - } \\
\text { USA }\end{array}$ & 1869 \\
\hline 6 & $\begin{array}{l}\text { Polish Academy of } \\
\text { Sciences Institute of } \\
\text { Biochemistry and } \\
\text { Biophysics } \\
\end{array}$ & 4 & Siemens - EU & 1871 \\
\hline 7 & $\begin{array}{l}\text { Institute of Electronic } \\
\text { Materials Technology }\end{array}$ & 4 & Qualcomm - USA & 1704 \\
\hline 8 & $\begin{array}{l}\text { Warsaw Medical } \\
\text { University }\end{array}$ & 4 & General Electric - USA & 1628 \\
\hline
\end{tabular}

Source: Our own analysis of information from the EPO

In this respect, the situation in Poland differs from that in other countries. Overall, universities and other such entities generally account for $5-6 \%$ of patent applications at the EPO. Most applications over $65 \%$ - come from large companies. This does not mean, of course, that universities outside Poland are not 
interested in patent protection for their inventions. On the contrary, universities in developed countries seek such protection very often. The number of patents obtained in $2010-2015$ by the 10 most innovative universities in Europe is presented in Table 6.

Table 6: Top 10 innovative universities by the number of patents granted in 2010-2015

\begin{tabular}{|c|l|c|}
\hline Position & Name & Number of patents \\
\hline 1 & University of Oxford & 443 \\
\hline 2 & University of London & 387 \\
\hline 3 & Technical University of Denmark & 330 \\
\hline 4 & Pierre \& Marie Curie University - Paris 6 & 305 \\
\hline 5 & University of Claude Bernard - Lyon 1 & 300 \\
\hline 6 & KU Leuven & 292 \\
\hline 7 & Imperial College London & 281 \\
\hline 8 & Swiss Federal Institute of Technology Zurich & 276 \\
\hline 9 & Ghent University & 238 \\
\hline 10 & Federal Polytechnic School of Lausanne & 235 \\
\hline
\end{tabular}

Source: our own analyses of information from Reuters Top 100 European Innovative Universities Comparison 2017

Foreign universities submit several to several times more patent applications than the best universities in Poland in this respect. For example, for many years, the most active higher education institutors have been the University of California (434 PCT patent applications in 2016), in 35th place, and the Massachusetts Institute of Technology (236 applications), in 83rd place (Patent Cooperation Treaty, WIPO, 2017, 32).

\section{Determinants of patent protection management at scientific entities in Poland}

The increased importance of intangible assets in the development of individual organizations and the economy at large, globalization processes, and the whole spectrum of consequences thereof (including qualified workforce mobility, accelerated technical progress, market expansion, shortening product and technology life cycles), along with intensive ICT technology development, mean the issue of protecting intellectual property is not as simple and obvious as it seems. There are a number of dilemmas, ranging from whether how to protect such property, how to manage intellectual property protection in order to avoid basic mistakes and to solve problems arising in this area (Wiśniewska, 2016, 270). These issues also concern the protection of various types of scientific research results, in particular technical inventions.

The need to move away from the "closed innovation" model toward the so-called "open innovation" model is ever more apparent (Pachura, 2017, 175). These trends are additionally strengthened by the resulting increase in innovation levels and by the "free revealing" concept, and will certainly affect the current R\&D management models in the coming years. This does not mean, however, that the protection of inventions is any less important. As results from research and observation, the "open innovation" model and the abandonment of exclusive rights to inventions stimulate first and foremost the appearance of imitation inventions. In turn, breakthrough solutions are created in closed systems and require protection, which may provide their creator with a kind of gratification for the risk and effort (financial, organizational, and temporal) involved in development and commercialization thereof (Wiśniewska, 2017, 315).

Without indicating whether the monopoly resulting from the patent is actually a stimulator or barrier to innovation 
processes, it should be stated that there are a number of factors affecting the decisions of an entity in this respect.

According to the analyses conducted, almost half of all inventions in Poland are the work of scientific and academic institutions, whose patent activity in comparison with other sectors is higher than in other developed countries. There are a number of factors determining whether patent protection is undertaken.
In addition to the obvious potential advantages and disadvantages of this type of protection, which may encourage or discourage any inventor within a certain scope, there are some conditions which are particularly important from the point of view of the academic sector. A summary of the basic stimulating and inhibitory factors, as well as the advantages and difficulties associated with patent protection from the point of view of the academic sector in Poland, is presented in Table 7 .

Table 7: Essential stimulators and barriers to applying for patent protection from the point of view of the academic sector in Poland

\begin{tabular}{|c|c|}
\hline Stimulators (benefits) & Barriers (difficulties) \\
\hline $\begin{array}{l}\text { - A temporary, formal monopoly } \\
\text { under intellectual property rights } \\
\text { which may be subject to transfer; } \\
\text { - Allows for trade in intellectual } \\
\text { property rights and financial gain } \\
\text { from licensing; } \\
\text { - Allows for access to information on } \\
\text { other technologies } \\
\text { - Positively affects the image of the } \\
\text { scientific entity (a kind of } \\
\text { confirmation of its scientific } \\
\text { potential) } \\
\text { - Has a positive effect on the } \\
\text { assessment of employees in the } \\
\text { evaluation process } \\
\text { - Positively influences the assessment } \\
\text { in the process of parameterization of } \\
\text { a scientific entity } \\
\text { Requirements of internal university } \\
\text { regulations regarding intellectual } \\
\text { property protection, resulting from } \\
\text { the Higher Education Act } \\
\text { Formal requirements in the } \\
\text { implementation of a number of types } \\
\text { of scientific projects financed from } \\
\text { public funds }\end{array}$ & 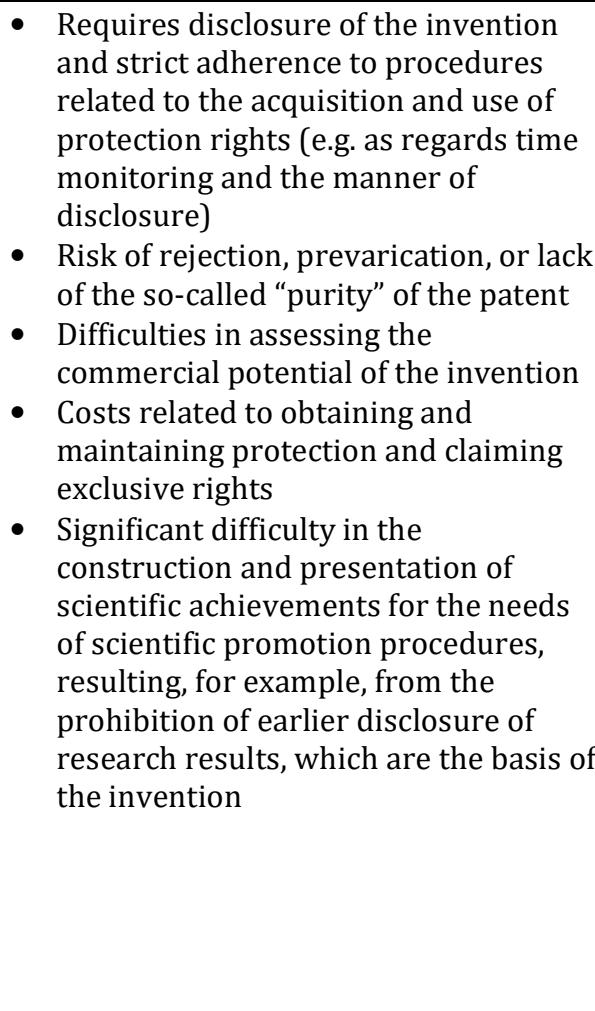 \\
\hline
\end{tabular}

Source: Our own analysis

Aiming to support the commercialization processes of the results of scientific research as well as implementation of European Commission and WIPO directives regarding intellectual property management as part of activities related to the transfer of knowledge, the Ministry of Science and Higher Education in Poland, by way of amendment to the Law on Higher
Education, obliged subordinate units to create the organizational and administrative conditions necessary for the proper management of intellectual property. On this basis, universities have developed and implemented relevant regulations and strategies. This activity has become one of the additional stimuli of the patent activity of the academic sector. 
However, despite the fact that patent protection of research results should favor the processes of commercialization thereof, in Poland, paradoxically, few of the inventions reported by scientific entities to patent offices find practical application in the economy. This thesis is confirmed by research audit activities of research institutes conducted by the Supreme Audit Office (NIK), which established that only $20 \%$ of patents obtained by research institutes, $14 \%$ of patents belonging to units of the Polish Academy of Sciences, and $4 \%$ obtained by universities were subject to practical use (NIK Report 2015, 21).

The existence of a problem with the commercialization of research results generated by scientific units is quite commonly emphasized, in turn translating into low effectiveness of the research undertaken and expenditures incurred for such purpose (including the costs of applying for legal protection). It should be emphasized that in developed countries less than $50 \%$ use of patented developments in practice is considered ineffective.

According to the NIK report, in 2011-2014 commercialization activities and the valuation of protected technologies concerned only a few percent of the intellectual property owned by the universities audited (NIK Report 2016, 4647). This situation may result from several factors, among which one stands out: lack of financial resources for implementing the patented solutions, low implementation/commercialization of patented inventions, non-economic reasons for filing patent applications, e.g. requirements for settlement of funds raised from EU funds or criteria for parametric evaluation of the university.

Moreover, a noticeable phenomenon in the case of inventions reported by universities in Poland is the relatively short period of patent protection. In 2011-2013, on average, $43 \%$ of patents awarded in a given year expired the end of the respective year. Only $28 \%$ of patents remained in force after 2 years. The data indicate that universities forgo protection for a significant number of inventions in the shortest possible time due to the lack of implementation potential, and the only reason for applying for legal protection thereof is to obtain the appropriate score in the parametric evaluation, which translates into funding for scientific entities in Poland (NIK Report 2016, 46-47).

\section{Conclusions}

The specificity of the situation in Poland compared to other developed countries in the world is based on relatively high application activity of universities in comparison to business units. As it appears from the presented rankings, in Poland, universities occupy the highest positions in terms of complex patent applications for both PPO and EPO.

The research undertaken, indicating selected phenomena accompanying the patent protection of the research results of scientific and research entities, highlights some of the existing problems and dilemmas which must be solved.

So far, tools to stimulate the commercialization processes of research results in Poland (including incentives to protect the intellectual property of the academic sector), as it turns out, do not sufficiently contribute to the stimulation of such processes.

Despite the fact that the level of patent protection applied for by research units in Poland is consistently growing, it is still significantly lower than the number of applications filed by such entities in more developed countries.

Another problem is the low percentage of practical implementations of university patents. Certainly, this situation is the result, inter alia, of the lack of a sufficient cooperation with the business sector. One of the basic reasons for this state of affairs is the generic structure of $R \& D$ works carried out in Poland. An important disadvantage of this structure, especially in the case of universities, is the relatively large share of basic research in relation to applied research and development works. 
Consequently, this means little or no cooperation between the two sectors in the field of scientific research (Janasz, Wiśniewska, 2017, 20).

The reluctance of enterprises regarding solutions (inventions) proposed by universities is often due to the lack of information on the technologies offered, or the perception of such as requiring considerable expenditure and failing to take into account the current competitive conditions. This is related to the specificity of work on so-called "university technologies," which to a greater extent focuses on the search for discoveries than the application thereof. Therefore, these technologies are often completely new to the market and, while remaining at the early stages of their life cycle, usually require more investment to develop or build appropriate competences for practical application thereof (Trzmielak, 2013, 116-117). Therefore, although they may potentially have a strategic competitive advantage, they are associated with greater risk and expenditure, and thus are of little interest to enterprises, especially from the SME sector, which is dominant in the Polish economy.

The following, among others, are not without significance with regard to commercialization and research result protection problems in Poland: still insufficient knowledge and experience of the scientific community in the relevant area, variable legal and regulatory conditions, costs and finance-related problems. The identified barriers to commercialization are many and various, including economic, legal, mental, etc. The abolition of such barriers would certainly stimulate science and research entities not only to widely undertake further research work, but also economically justify the processes of applying and maintaining patent protection for inventions which were initiated by universities.

\section{References}

1. 'Act of 30 April 2010 on the principles of financing science', OJ (2016) item 2045, as amended.
2. Janasz, K. and Wiśniewska, J. (2017), 'Aktywność innowacyjna przedsiębiorstw w Polsce.' In: Kaczmarek, J., Krzemiński P. (ed), Doskonalenie działania przedsiębiorstw i instytucji wobec przemian społeczno-gospodarczych. Innowacje-Finanse-Otoczenie biznesu. Fundacja Uniwersytetu Ekonomicznego w Krakowie, Kraków.

3. Máté, D., Oláh, J., Laknern, Z., Popp J. (2017), 'Food Chemistry Patents Influence of Productivity: a Case Study of a Sectoral Approach in Various OECD Countries', Polish Journal of Management Studies, 16 (2), 160-170.

4. NCBiR Report (2015),'Assessment of the state of readiness of the research and development sector in Poland with regard to the use of public-private financial investment instrument support opportunities in 2014-2020 as well as the possibilities for implementing such instruments by the National Centre for Research and Development' Report, Warsaw.

5. NIK Report (2016), 'Commercialization of the results of scientific research'. Information on the results of the NIK audit, Department of Science, Education and National Heritage", KNO. 410.006.00.2015, Warsaw.

6. NIK Report (2015), 'Contributions of research institutes to the achievements of Polish science', Information on the results of the NIK audit, Department of Science, Education and National Heritage", KN0.4101-009-00/2014, Warsaw.

7. Pachura, A. (2017) 'Innovation and Change in Networked Reality', Polish Journal of Management Studies, 15 (2), 173182.

8. 'Patent Cooperation Treaty' (2017). Yearly Review. The international patent system, WIPO 2017.

9. 'Reuters Top 100 European Innovative Universities' (2017). [Online] Comparison [Retrieved January 26, 2018], https://www.reuters.com/article/us- 
amers-reuters-ranking-innovativeuniv/reuters-top-100-the-worlds-mostinnovative-universities-2017idUSKCN1C209R.

10.Sawulski, J. (2018), Efektywność wydatków na badania i rozwój w Polsce na tle innych państw Unii Europejskiej, Difin, Warszawa.

11.'The Law on Higher Education Act', OJ (2016) item 1842, as amended.

12.Trzmielak, D.M. (2013), Komercjalizacja wiedzy i technologii-determinanty i strategie, Wydawnictwo Uniwersytetu Łódzkiego, Łódź.
13.Wiśniewska, J. (2016), Aktywność patentowa $\mathrm{w}$ praktyce funkcjonowania przedsiębiorstw w Polsce. In: Kaczmarek, J., Litwa P. (ed), Procesy rozwoju przedsiębiorstw w konkurencyjnym i innowacyjnym otoczeniu. Fundacja Uniwersytetu Ekonomicznego w Krakowie, Kraków.

14.Wiśniewska, J. (2017), 'Ochrona wynalazku w procesie zarządzania działalnością badawczo-rozwojową', Studia i Prace Wydziału Nauk Ekonomicznych $i$ Zarządzania Uniwersytetu Szczecińskiego, 48 (3), 307-318. 